

\title{
OBSTACLES IN LAW ENFORCEMENT AGAINST PERPETRATORS OF SEXUAL ABUSE INFLUENCED BY PORNOGRAPHY IN TERRITORY OF BENGKULU DISTRICT COURT
}

By:

\author{
Ainul Mardiati, Herlambang, M. Abdi
}

\begin{abstract}
Indigenous village is important, therefore, it is required the establishment of indigenous villagein the respective regencies in Indonesia. To form the indigenous village needs to see some supportingaspects.One of sub-district which has a supporting aspect in the formation of indigenous villages in North Bengkulu is Enggano District. The research objective isto know and analyze the obstacles faced in implementing Law No. 6 of 2014 in the establishment of indigenous village in Enggano District of North Bengkulu. The methodology used is empirical juridical approach, byusing qualitative analysis. The result study showed that the obstacles encountered in the implementation of Law No. 6 of 2014 on Village in the establishment of the indigenous village in Enggano District of North Bengkulu consisted of two factors:Internal and external factors.
\end{abstract}

Keywords: Obtacles, Law Enforcement for Perpetrators of Pornography Sexual Abuse 


\section{A. INTRODUCTION}

\section{Background}

The Republic of Indonesia is a constitutional state listed in Article 1 verse (3) of the Constitution which states "Indonesia is a State of Law (Rechstaat). ${ }^{1}$ that symbolizes on Pancasila with motto of Bhineka Tunggal Ika (Unity in Diversity)whichis upholding of moral values, ethics, character, and personality of the noble nation, faith and fear of God Almighty, respecting diversity in the community, the nation, and the state, as well as protecting the dignity of every citizen. ${ }^{2}$

National development is the development of Indonesian fully and completely, so in the development of the nation it should reflect the personality of Indonesia including the development of moral values that is implicitly included in the national development goals. ${ }^{3}$ Development of national law that is implemented to

1 Undang-undangdasar 1945 (Amendment Completed)

${ }^{2}$ General Eludication of Law number 44 of 2008 on Pornography in the first paragraph

${ }^{3}$ General Eludication of Law number 44 of 2008 on Pornography in the first paragraph. anticipate the rapid development of globalization in economic, trade and development of science and technology makes the law which should be as a rule preceded the social dynamics can not play a role as social engineering that gives the base and at the same direction of development in order to remain in accordance with the insight and the noble values of Indonesia national identity. ${ }^{4} \mathrm{~A}$ wide variety of legal issues that arise today is in line with the current development, science and technology which is increasing rapidly. One of the most urgent problem is pornography. Pornography has changed the behavior patterns of an increasingly complex society. The more patterns of human behavior occur that does not comply with the norms prevailing in society. Deviant behavior is what can lead to a criminal act.

Sexual abuse continues to grow until now. The average victims of sexual abuse are children. The high sexual abuse cases happened because of parents'low supervision to their children. The

\footnotetext{
${ }^{4}$ JurnalPembaharuanHukumVolume I No. 2 May-August 2014. Accessed on $17^{\text {th }}$ of March 2017, at $12.30 \mathrm{pm}$
} 
perpetrators perform their action when children are out of the parents'supervision. The cases occurred is generally preceded by perpetrators after watching movies/images of pornography. For every normal person based on the experiences of people in general, when reading or viewing pictures or objects such statues or dolls, will attack the sense of decency like embarrassed or disgusted or possibly guilty. ${ }^{5}$

Based on the author'spreliminary research on sexual abuse in Bengkulu City, the author found some examples of the cases that occurred in February of 2014 by the defendant of aAdult Male named M.UE, age 42, who worked as a civil servant in Bengkulu city with numbers register report No. LP/B1015/V/2017/RES.BKL dated May $10^{\text {th }}$, 2017. In that case, M.UE committedsexual abuseby rapping the victim repeatedly and threatening to use a kris (knife sewar) to kill the victim, it was committed by the suspect to the victim with the excuse to make the victim's body stronger, so the suspect and the victim

\footnotetext{
${ }^{5}$ AdamiChazawi, 2005, Tindak Pidana Mengennai Kesopanan, PT. Raja GrafindoPersada, Jakarta, Pg. 22
}

must remain intercourse.

Based on the chronological case, it is very clear that the suspect M.EU had violated the provisions set in Article 81 verse (1) jo Article 76D of Law no. 17 of 2016 regarding the Stipulation of Perppu No. 12016 joPerppu No. 1 of 2016 on the second amendment of Law No. 23 of 2002 on Child Protection. The criminalcase committed by M.UE had been through the trial process in Bengkulu District Court, and sentenced to a criminal for 11 years and 3 months.

Apart from the example above, there are also criminal cases of abuse that occurred in October 2017 conducted by the Adult Male named RP aged 39, who worked as a night watchman in the register number report No. LP/B2190/X/2017/RES.BKL October $20^{\text {th }}$, 2017. In that case, RP first hit the victim's thigh using a broom handle, then the suspect immediately ordered the victim to open her pant. Due to fear, the victim did everything asked by the suspect and then the suspect raped the victim till crying. RP charged with having violated Article 81 or Article 82 of Law No. 17 2016 regarding the Stipulation of Perppu No. 12016 jo Perppu No. 1 of 2016 on 
the second amendment of Law No. 23 of 2002 on Child Protection. Currently the sentence (verdict) of the suspect is still in the process of final hearing. In addition there are examples of such sexual abuse cases against children affected by pornography in Bengkulu City. Dataobtained from Bengkulu Police for the casesin 2014 - 2016, showed that in 2014 had 17 cases, the cases that have sufficient evidence (P21) are 7 cases, the cases resolved outside the judicial process are 2 cases, the cases that had less evidence are as many as eight cases. In 2015 it had 13 cases, the cases that had sufficient evidence (P21) are 3 cases, the cases settled out of court process are 2 cases, the cases that were lacking evidence are 8 cases. In 2016, it had 13 cases, the cases that had sufficient evidence (P21) are 4 cases, the cases resolved outside the judicial process are as many as 4 cases, the cases that had less evidence are 5 cases.

Based on research data, itcould be seen that the criminal act of sexual abuse is needed an intensive indispensable efforts, both by law enforcement officials and the community by reducing the numbers of crime both in quality and quantity.

Based on the description above, the authors is interested to write a journal entitled "Obstacles in Law Enforcement against Perpetrators of Sexual Abuse Influenced by Pornography in Territory of Bengkulu District Court".

\section{Identification Of Problems}

The formulation of the issues raised in this paper is: What are the obstacles in Law Enforcement against Perpetrators of Sexual Abuse Influenced by Pornography in Territory of Bengkulu District Court?

\section{B. RESEARCH METHODOLOGY}

The method used in this research by its nature is a qualitative research approach to empirical laws. Qualitative research is research that takes a holistic approach, the approach that requires a variety of information to be analyzed, so as to understand certain aspects of human behavior. The nature of this research is empirical juridical.Juridical empirical legal research as a result of interaction between legal science with other sciences disciplines. ${ }^{6}$ This research

\footnotetext{
${ }^{6}$ Bahder Johan Nasution, Metode Penelitian Ilmu Hukum, Mandar Maju, Bandung, 2015,
} 
was conducted in BengkuluDistrict Court.

\section{RESULT AND DISCUSSION}

\section{Obstacles in Law Enforcement against Perpetrators of Sexual Abuse Influenced by Pornography in Territory of Bengkulu District Court}

Law enforcement against the perpetrators of sexual abuse influenced by pornography in territory of Bengkulu Police has been running at maximum, but it is still encountered several obstacles. It is obtained from interview with Indramawan Kusuma Trisna, S.Ik, Head of Criminal Investigation Unit of BengkuluPolice. That is often encountered various obstacles in the criminal law enforcement against perpetrators of sexual abuse influenced by pornography from the Police Bengkulu, namely:

a. Evidence, Evidence is important in the examination process. In accordance with the content of Article 184 Criminal Procedure Code, valid evidence are: The testimony, Specification Expert, Letters, and Defendant's Help Description.

pg. 123
Usually the witness in a sexual abuse case is the victim. In addition there are also witnesses such as parents' victim, families, friends of victim, and so forth. However, the evidence provision of witnesses other than the victim's witnesses should be excluded in accordance with the provisions of Article 185 of Criminal Procedure Code, for example, the witness is the victim's parents who only informed of the sexual abuse fromtheirchildren (the victim) without seeing directly the incident. If there is only one witness who saw or heard or experienced by herself (the victim) of the offenses, the suspecthas a chance to deny his actions. Especially against the penalty of minimum 5 years, the defendant must be accompanied by Legal Counsel.

b. The victims or their families do not want to report the sexual abuse against children, this can be caused by:

a) Rapporteur is asked to make peace

b) Rapporteur is threatened, so that the complainant does not dare to 
report suspect to the authorities.

c) Families of victims will feel embarrassed to report the suspect because it would be a dishonor to their families forever.

c. The suspect fled, the difficulty of finding the existence of the perpetrator. Eg, moving out.

d. The perpetrator is a minor

Perpetrators of sexual abuse influenced by pornography is sometimes very vulnerable committed by children who are still minors, thus making it difficult for the police to handle the case. Because the police would be difficult to carry out checks to suspects who are still minors. Sometimes in providing information they are not clear because of the fear of crime that they did.

M. Zaenur Kosin, PS. Chief Unit of PPA, also adding obstacles/constraints faced by Bengkulu Police in law enforcement against perpetrators of sexual abuse influenced by pornography in Bengkulu City, namely:

a. The imposition of law is lighter than the evil deeds

b. There are still gaps legal loopholes that can be used to commit a crime.

c. The ability of law enforcement officers who still need to be improved, so that no one escapes criminal offense of reach.

d. There is still a difference of opinion among law enforcement officers to the interpretation and the material provisions of the law.

Meanwhile, according to

Azizah Yuli Susanti, SE., Vice Investigator Unit of $P P A$ of Bengkulu Police, explained that in addition to the obstacles mentioned above, also often encountered obstacles / barriers else in law enforcement against perpetrators of sexual abuse influenced by pornography that victims feel ashamed, afraid to report the incident to the police, the victim is under pressure/threatened. Thus to overcome these obstacles, Bengkulu Police make efforts including:

a. Do a post mortem on the victim

In sexual abuse, not all victims immediately reported the event, sothe autopsy report does not indicate any molestation. And to prove the sexual abuse should be 
done post mortem.

b. Seek and publish the List of Wanted Person

For offenders who flee, the police will come to the family suspects and gather evidence. If the evidence is sufficient, then the police will issue a List of WantedPerson.

c. If the culprits are children, police conductes Diversion to the suspect.

Diversion is a child's diversion settlement of the criminal justice process to the outside of the criminal justice process. Namely by promoting peace track because it concerns the future of the child in spite of him as the culprit.

Based on interview with Rozano Yudisthira, S.H., M.H., that in the handling of law enforcement against perpetrators of sexual abuse influenced by pornography, Bengkulu State Attorney do not find obstacles of infrastructure and the means, it is just the victim of abuse called for questioning in the hearing often reject to come because of shame and trauma, the timing of new criminal offenses came to light after the evidence is lost, the witness withdraws his statement in the court, the different perception between the investigator and the prosecutor on the instructions of the public prosecutor in the investigation file, the different perception between the public prosecutor and the judge in the process of proving in the trial.

Zubaidah isadding to overcome the obstacles on sexual abuse influenced by pornography in Bengkulu State Attorney through two phases: phase of pre-prosecutionand prosecution. Pre-prosecution is proving a criminal case done after prosecutors received the case file of the investigation, the public prosecutor later studies and investigates the completeness of case file. The research is carried out in the form of:

- Completeness of the Investigation Report;

- The validity of the investigating actions related to searching, confiscating, reports and 
evidence;

- Other actions that must comply with the Act.

\section{RozanoYudisthira, S.H.,} M.H.,explained that the prosecution phase of the preparatory activities delegated to the court is to determine whether the case is filed as usually, shortly or fastly. After that, the public prosecutor makes an indictment. In the prosecution phase, it is a determinant of the criminal case. Because at this stage once the accused has confessed nonetheless, Prosecution will prove again.

\section{According}

toSuparman generally the law enforcement of sexual abuse in the Bengkulu District Court has no barriers, but this little custom in the community still not openly dares to express the actual incident, it is usually because the family would be embarrassed to disgrace the victim disclosed, and usually the perpretator likes convoluted in giving his testimony, the perpetrator's knowledge about sexual abuseis lack, the perpetrator is not accompanied by the Legal
Counsel.

The judge Haskaryo added that usually to deal with these obstacles the judge made an explanation with the victim who did not want to tell the story by the defendant / through being released from the trial when the judge askes for information from the victim witness, the judge tries to give a bit of legal explanation to the perpetrator, then conducted coaching with the child defendant.

Haskaryo explained that the obstacles/constraints faced by judges in law enforcement against perpetrators of sexual abuse influenced by pornography, are common obstacles such as the perpetrator does not want to acknowledge his actions, victims especially children do not want to tell about the occurrence of abuse because of shame, while in the victim's family it is still covered because it is related to disgrace. To overcome the obstacles, it is usually done by persuasive approach such as through counseling (involving psychologists, social workers who care for victims of sexual abuse, 
through the clergy to provide spiritual cleansing routine to the victim, motivator for the supporting the spirit of the victim from being dropped in the future.

According to Aldikan, the handling of children in conflict with the law at this time has not been able to be implemented in an integrated manner by law enforcement officials related to the tasks of the Correctional Center. Because it seems that there is a prominent interest in each apparatus. Thus the best interests for childrenscan not be realized resulting in the emergence of problems:

1. Lack of a common perception of the relevant law enforcement and child in court proceedings in order to find the best solution for the best interests of the child

2. All children in conflict with the law are investigated by Supervising Community $(P K)$ and tried in court involving $P K$ from the Penitentiary, as well as Litmas results have not been fully taken into consideration to find the best solution for the children.

3. Human Resources, due to social research data submitted should be valid. But most of the data presented is not complete.

The protection form conducted by Supervising Community such as by:

a. Initial assistance and make Litmas (social research) at the investigation step, directing to what is best for the children to investigators and judges on the court.

b. Litmas is in the judicial process and attending thecourt proceedings

c. Recommendations must be taken into consideration by the judge

d. $L P K A$ initial formation of children is through Litmas programs

e. If at the stage of obtaining Conditional Leave $(C B)$ and Conditional Exemption $(P B)$ from a child Correctional Institution, then the task of Bapas in this case represented by a community officer $(P K)$ is directing by guidance and coach to children by providing useful skills for the child such as: workshop, driving courses, sewing courses and cooking for girls and others

f. Coordinated with law enforcement officers, family, community leaders and fellow $P K$ associated with the best solution for the Children's Future.

Aldikan describedthat the obstacles encountered in Correctional Center Class II of Bengkulu in Law 
Enforcement against perpetrators of sexual abuse which are influenced by pornography, namely:

a. The weakness of law rule that applies to the children'scriminal, which includes no mention of sanctions if there isn't administrative requirements in solving criminal cases, especially children in court proceedings;

b. Lack of coordination among law enforcement officers in a particular handling criminal cases done by the children

c. The low quality of human resources in the Correctional Center Class II of Bengkulu. so that in handling criminal cases the child does not act professionally.

d. The lack of adequate facilities and infrastructure, so that in the handling of children's criminal cases can not do their job in the preparation of social research reports which are not based on the schedule.

e. The legal area of the Correctional Center Class II in Bengkulu is very wide, consisting of 9 Districts, 1 City, and Enggano Island. If it is traveled by land will take approximately 8 hours of travel, ideally one district and one Bapas.

f. There is no assessors in Bapas, because to make the assessment,there should be the assessors, this is due to the spread of uneven assessors in Indonesia, at least one Bapasthere are two assessors.

g. Lack of cooperation between the client's family and the attendant of social counselors, thus it is a bit difficult to get information about the childclient.

The effort from Bapas Class II of Bengkulu related to the handling of children problems who committethe criminal acts is to seek the best for child, whether in sanctioning, coaching and supervisingthe children who are dealing with the law.

Based on the interview results above, there are still obstacles in the Law Enforcement against perpetrators of sexual abuse influenced by pornography in Bengkulu District Court whether at the police, prosecutor's office and the Court. This illustrates that the efforts of law enforcement officials have not been 
maximized in tackling empirical crimes, as expressed in A.S. Alam (2010), the efforts to overcome empirical crime can be

done in three ways, namely: ${ }^{7}$

\section{a. Pre-Emptive}

What is meant by Pre-Emptive effort here is the initial efforts made by the police to prevent crime. The efforts made in preemptive crime prevention is by instilling good values / norms, so that these norms are internalized in a person. According to the author's analysis, this has not gone well, where the socialization carried out in order to instill moral values is still relatively minimal. Thus the efforts to overcome them is not running optimally.

b. Preventive

These preventive measures are a follow-up to the pre-emptive efforts that are still at the level

\footnotetext{
7 A.S.Alam, Pengantar Kriminilog, Makassar, Pustaka Refleksi Books, 2010, p. 79
}

of prevention before the occurrence of crime. According to the author's analysis, the prevention efforts made by the police to eradicate sexual abuse influenced bypornography whether from pornographic content, videos and images are still very minimal. This was evidenced by the absence of raids against thetraders of pornographic pirated VCD in the territory of Bengkulu Police. Whereas with the circulation of the VCD, it is the main cause of sexual abuse criminal acts.

c. Repressive

This effort is carried out aftercrime in the form of law enforcement by imposing a sentence. According to the author's analysis,this effort has been carried out, but not yet maximal where often for perpetrators that are under the age, themaximum sanctions cannot be applied. This is to protect the rights of the perpetrator as a child who also 
needs to be protected by the State.

Based on the interview result above, it could be concluded that the obstacles in the Law Enforcement for perpetrators of sexual abuse influenced by pornography in the Bengkulu District Court whetheris at the police, prosecutors or courts are as follows:

1) The juridical obstacles

The juridical obstacles is resistance that comes from legislation, where the regulations are sometimes contained inconsistenin applying the sanctions, which in tackling acts of abuse are influenced by VCD and video as well as images that content of pornographic, the law has not been set explicitly to the spreader, multipliers, sellers and buyers of the pornographic content itself.

2) The sociological obstacles

The sociologicalobstacles comes from social and environmental obstacles, where their families and the victims are sometimes reluctant to report incidents of sexual abuse because of embarrassment's fear.

\section{CLOSING}

\section{Conclusion}

The obstacles in the Law Enforcement against perpetrators of sexual abuse influenced by pornography in Bengkulu District Court whether is at the police, prosecutors or courts are as follows:

1) The Juridical Obstacles The juridical obstacles is resistance that comes from legislation, where the regulations are sometimes contained inconsistent in applying the sanctions, which in tackling acts of abuse are influenced by VCD and video as well as images that content of pornographic, the law has 
not been set explicitly to the spreader, multipliers, sellers and buyers of the pornographic content itself.

2) The Sociological Obstacles. The sociologicalobstacles comes from social and environmental obstacles, where their families and the victims are sometimes reluctant to report incidents of sexual abuse because of embarrassment's fear.

\section{Suggestion}

Based on these conclusions, the researcher expressedthe suggestions as follows:

1. For law enforcement against perpetrators of sexual abuse influenced by pornography are actually enforced in accordance with the applicable rules and regulations. Therefore it can be provide a deterrent effect for the perpetrator not to repeat his actions.

2. For law enforcement officers to be more able to protect the community,so that cases do not happen again. And it is expected that the disclosure of this case can be more perfect. Criminal casesof sexual abuse influenced by pornography are not an ordinary case, thus it requires more serious treatment.

3. Those parents should be more vigilant with greater control over their children because of the rapid development of technological progress nowdays, so that children do not become perpetrators or become victims of sexual abuse influenced by pornography.

\section{REFERENCES}

Adami Chazawi, Tindak Pidana Mengenai Kesopanan, PT. Raja Grafindo Persada, Jakarta, 2005.

A.S. Alam, Pengantar Kriminilogi, Makassar, Pustaka refleksi Books, 2010

Bahder Johan Nasution, Metode Penelitian Ilmu Hukum,Mandar Maju, Bandung, 2015

Jurnal Pembaharuan Hukum Volume I No. 2 mei-agustus 2014. Diakses tanggal 17 maret 2017

Sirman Dahwal, Pelaksanaan Perkawinan Beda Agama (Studi Berbagai Kasus Di Indonesia Priode Tahun 19862010), Jurnal Ilmu Hukum 


$\begin{array}{lrr}\text { Bengkoelen } & \text { Justice,Program Pasca } \\ \text { Sarjana Ilmu } & \text { Hukum } \\ \text { vol.2.No.2.2012. }\end{array}$

\section{Regulations}
Undang-Undang Dasar Negara Republik Indonesia tahun 1945

Undang-undang no. 32 tahun 2002 tentang Perlindungan Anak

Undang-Undang No, 44 Tahun 2008 tentang Pornografi.

\section{KUHP}

Kamus Hukum, 2011, Bandung, Citra 
